BIOLOGY AND FISHERY OF DOLPHINFISH AND RELATED SPECIES. E. MASSUTÍ and B. MORALES-NIN (eds.)

\title{
Fish associated with fish aggregation devices off the Canary Islands (Central-East Atlantic)*
}

\author{
J.J. CASTRO, J.A. SANTIAGO and V. HERNÁNDEZ-GARCÍA \\ Departamento de Biología, Universidad de Las Palmas de Gran Canaria, Apdo. 550, Las Palmas de Gran Canaria, \\ Canary Islands, Spain. E-mail: josejuan.castro@biologia.ulpgc.es
}

\begin{abstract}
SUMMARY: Sixteen fish aggregation devices (FADs) were deployed in 50 to $500 \mathrm{~m}$ deep of water in the Canary Islands. Species composition and abundance were determined by visual census carried out by divers on 55 occasions from April to October 1995 and from August 1996 to May 1997. A total of 15 species representing nine families of fish were observed. Pseudocaranx dentex (Bloch and Schneider, 1810), Seriola spp. and Naucrates ductor (Linnaeus, 1758) were the most abundant species. The number of species associated with FADs increased with immersion time, but fish biomass did not increase. The maximum number of fish species registered exactly under the FADs at any one time was five. The average estimated biomass was $9.47 \mathrm{Kg}$ per $\mathrm{FAD}$ ( $\mathrm{SD}=25.2$ ). However, when only baitfish were taken into account, the mean aggregated fish biomass was $3.20 \mathrm{Kg}(\mathrm{SD}=4.32$ ). The estimated biomass was higher when Coryphaena spp. was present, increasing to 53.9 $\mathrm{Kg}$ per FAD ( $\mathrm{SD}=53.6)$. A significantly lower fish biomass and number of species was observed in FADs deployed in shallower waters (50-100 m depth).
\end{abstract}

Key words: FADs, Fish assemblages, floating structures, artisanal fisheries, Central-East Atlantic.

\section{INTRODUCTION}

The tendency of fish to aggregate around floating objects has been known for some time (Mortensen, 1917; Uda, 1933; Kojima, 1956; Galea, 1961; Hunter, 1968). The first commercial fish aggregation devices (FADs) were deployed in the waters of the Philippines in the early 1970s (Kihara, 1981) to attract Thunnus albacares (Bonnaterre, 1788). Due to the success of FADs in aggregating fish, these have come to play an important role in the commercial, subsistence, and recreational fisheries of all the tropical and sub-tropical oceans of the world (Pollard and Matthews, 1985; Frusher, 1986; Wilkins and Goodwin, 1989; Biais and Taquet, 1990; Hol-

Received January 20, 1998. Accepted January 21, 1999. land et al., 1990; Buckley and Miller, 1994; Friedlander et al., 1994; Higashi, 1994; Kitamado and Kataoka, 1996).

This fishing method has most specifically been used in large scale commercial tuna fisheries over the last three decades and has given a higher yield of fish (Greenblatt, 1979; Fonteneau, 1992). The method yields an average catch of 40 tonnes of tuna per fishing operation around flotsam in comparison with 20 tonnes for free schools (Fonteneau and Hallier, 1993). Sometimes up to 200 tonnes of tuna have been harvested in a single fishing operation (Sacchi, 1986).

The first studies designed to ascertain the mechanisms leading to aggregation under floating objects were carried out by Gooding and Magnuson (1967) and Hunter and Mitchell (1967). Subsequent to 
these, there have been many more including those by Greenblatt (1979), Matsumoto et al. (1981), de Silva (1982), Myatt and Myatt (1982), Beets (1989), Buckley et al. (1989). Four methods have been used to study the fauna associated with flotsam: 1 . direct observation (Rountree, 1989; 1990; Parin and Fedoryako, 1992); 2. use of fishing (Hunter and Mitchell, 1967; Massutí and Reñones, 1994); 3. combination of both (Wickham and Russell, 1974); 4. use of ultrasonic tags (Brill et al., 1984. Holland et al., 1990; Cayré, 1991; Cayré and Marsac, 1993).

Several hypotheses have been suggested to explain aggregation under floating objects (Kingsford, 1993). Amongst many other factors, the most appealing are: Fish congregate around flotsam looking for refuge from predators (Hunter and Mitchell, 1968; Feigebaum et al., 1989). Fish may aggregate because more food is available under flotsam (Gooding and Magnuson, 1967). The disturbance produced by the flotsam in the uniformity of the ocean may be a reason for the attraction (Holland et al., 1990; Hunter and Mitchell, 1967). However, it seems to be the consequence of many factors which influence fish behavior (Fonteneau, 1992; Hall, 1992; Kingsford, 1993).

Several fish species approach FADs looking for food, and feed on the invertebrate that grow on the FADs (i.e. hydrozoans, cirripedes, amphipods and crabs)(Kojima, 1967; Ida et al., 1967; Rountree, 1990; Massutí and Reñones, 1994). It is thought that large predators like tunas, sharks and dolphin-fish, are attracted by the fish aggregated under the FADs (Wickham et al., 1973, Arenas et al., 1992). However, there are doubts that these species prey on the fish fauna associated with the FADs (Brock, 1985; Cort, 1990; Fonteneau, 1992; Massutí and Reñones, 1994). It is also possible that some species like dolphin-fish use FADs as spawning places, due to the fact that drifting objects indicate the presence of oceanic currents where eggs and larvae may drift more efficiently towards better nursery areas.

Studies carried out on the fish communities associated with FADs off the West coast of Africa are few, and deal mostly with the large scale tuna fisheries under flotsam (Wood, 1989; Fonteneau, 1992; Kwei and Bannerman, 1993). In the Canary Island waters, there is no traditional commercial fishing around flotsam, and there is only one previous study on the fish communities associated with artificial habitats (i.e. FADs and cinder blocks on the bottom) (Bortone et al., 1994). In this paper, we describe the faunal composition and abundance of fishes associated with FADs anchored at the south of the island of Gran Canaria, using census data and information from commercial catches over two years. The aim of this paper is to study the fish community associated with FADs, and the variations in the number of species and biomass aggregated in relation to season, depth of anchoring and immersion time. Observation of the behaviour of the species associated with FADs was also recorded to provide further details on the fish community structure.

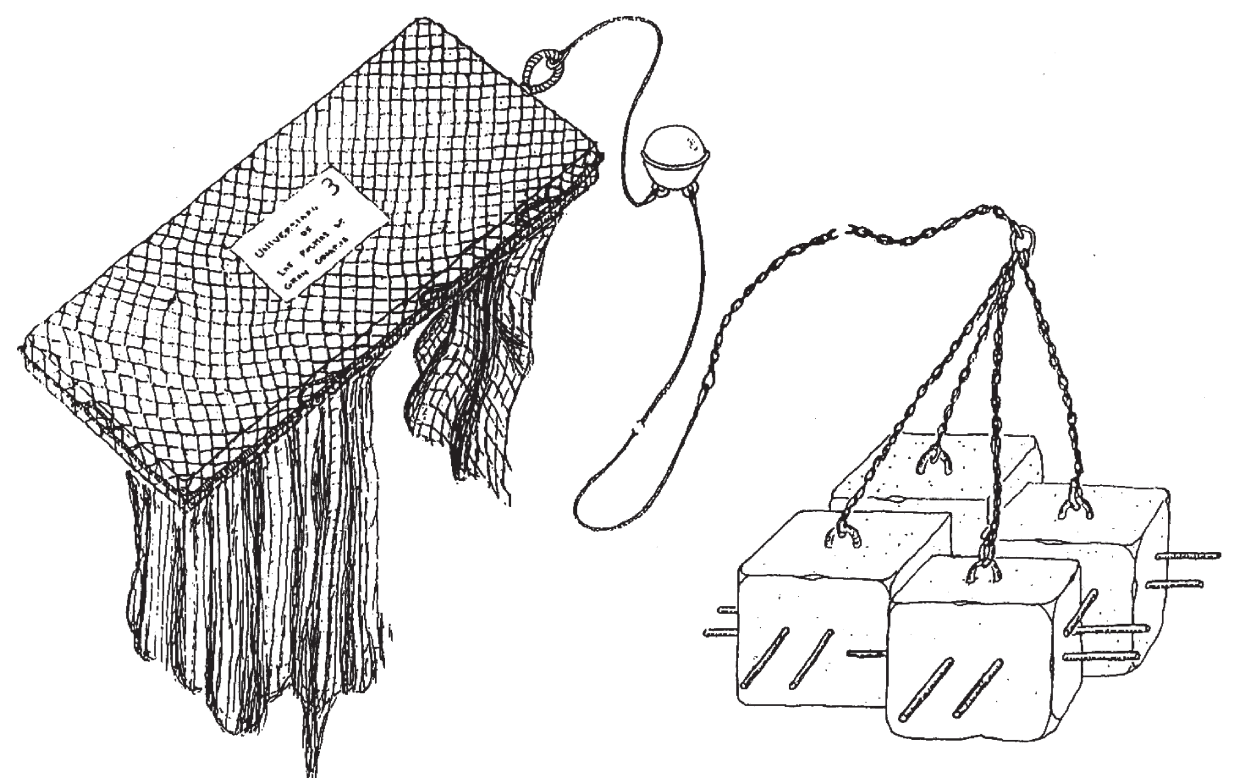

FIG. 1. - Fish Aggregation Devices and anchorages used during the study period. FAD was a mattress of foam (200x100x12.5 cm), covered with a black plastic film and a piece of net. The submerged volume was increased with fragments of old nets (about $1.5 \mathrm{~m}$ of longitude). The anchorage was composed of four $50 \mathrm{~kg}$ concrete blocks. 


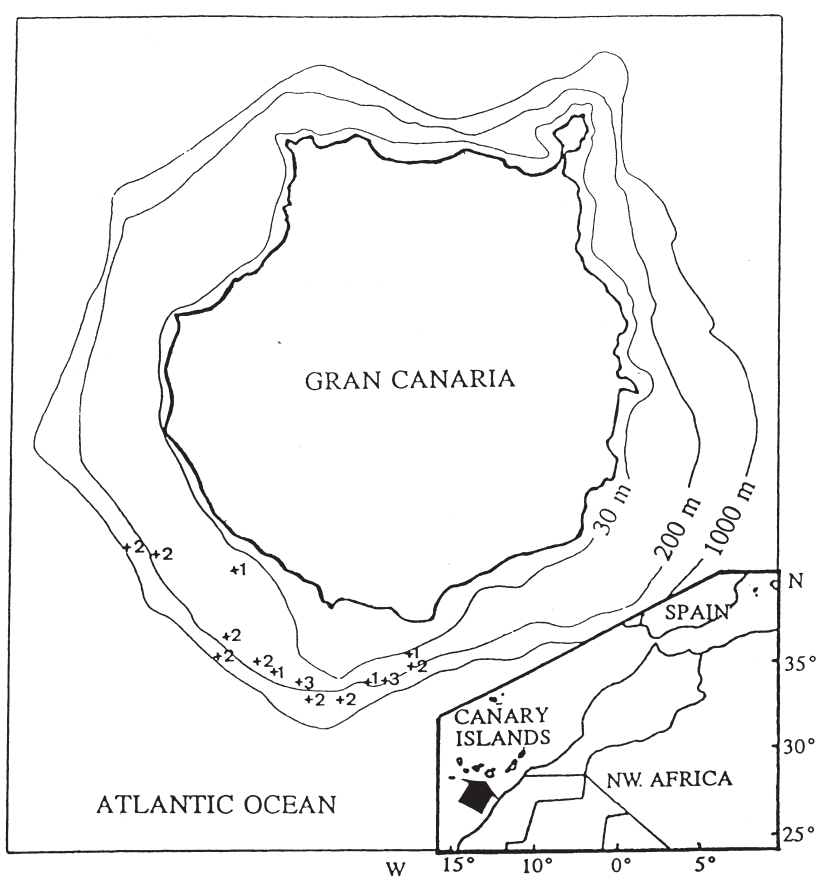

FIG. 2. - Location of the FADs deployed in waters off Gran Canaria (Canary Islands, Spain).

\section{MATERIALS AND METHODS}

In 1995, 1996 and 1997, 16 Fish Aggregation Devices (FADs) were constructed (four in 1995, ten in 1996, and two in 1997) using blocks of foam of expanded polystyrene $(200 \times 100 \times 12.5 \mathrm{~cm})$. These blocks were covered with a black plastic film to protect the "foam" from the sun and damage caused by seagulls. Each unit was netted to hold the flotsam to the anchor. The submerged float volume was increased by adding fragments of old nets (about 1.5 $\mathrm{m}$ in length) hanging from the float (Fig. 1). No float unit surpassed $10 \mathrm{Kg}$ in weight.

The anchorage of each FAD was composed of four concrete blocks, each weighing $50 \mathrm{Kg}$, held together with chains. The floats were tied to the anchorages using synthetic ropes about $20 \%$ longer than the depth of the area, to avoid sinking the FAD due to current or tidal drag. The FADs were deployed at depths between 50 and $500 \mathrm{~m}$ (Fig. 2). The cost of the FADs ranged between 200 and 370 US $\$$, depending on the depth of the anchorage.

From April until October 1995 and August 1996 to May 1997, observations of fish associated with the FADs were carried out almost fortnightly. The number of visits to the FADs in 1995 and 1996-97 were 26 and 29 respectively. During each of these visits, two divers undertook a visual census of all the fish within the range of visibility from the FADs (visibility around the FADs ranged from 15 to $30 \mathrm{~m}$ ). Divers recorded the number of fish of each species and their approximate size. The size (total length) recorded was transformed to weight, using the length-weight relationships of each species obtained from the literature (Isidro, 1990; García-Gómez, 1993; Gordo, 1996) and from our own non-published data. During observations, video recordings were also taken to verify the census and to provide records for use in subsequent studies of the behavior and spatial distribution of fish around the FADs.

We carried out a statistical analysis in order to test the following hypotheses: 1) Fish community change with the season of the year, as a consequence of the recruitment processes of the local fish fauna (sensus Rountree, 1990). 2) The depth of anchorage (50-100, 120-160 and $>300 \mathrm{~m}$ ) influences the fish community structure, so that we can expect to find fish biomass and the number of species associated to FADs increasing from shallow to deep waters. 3) The fish community is expected to increase the diversity of the species as immersion time and maturity increase (sensus Vinogradov, 1983).

We also logged the fish captures carried out 100 $\mathrm{m}$ around FADs by artisanal fleet based in nearby fishing ports. This fleet was composed of wooden vessels of 11-16 m length, using live-bait and trawling lines. Fishermen were provided with form sheets where they recorded the daily catches by FAD (all FADs were numbered to facilitate their location on a chart).

\section{RESULTS}

\section{Composition by species}

Nine families and 15 species of fish were observed under or near the FADs (Tables 1 and 2), eight of which had commercial value in the Canary Islands. Katsuwonus pelamis (Linnaeus, 1758) and Thunnus alalunga (Bonnaterre, 1788) were the most important species for the local market, followed by Coryphaena spp. (only after genetic analysis were we able to isolate $C$. hippurus Linnaeus, 1758 from C. equiselis Linnaeus, 1758, since visual census did not allow for segregation of both species), Seriola spp., and Pseudocaranx dentex (Bloch and Schneider, 1810). The most frequently observed family was Carangidae. 
TABLE 1. - Fish species associated with Fish Aggregation Devices in waters off Gran Canaria, recorded from diver visual counts from April 1995 to May 1997 (*fish species only recorded through fishing).

\begin{tabular}{|c|c|c|c|c|}
\hline Family & Species & $\begin{array}{l}\text { Length range } \\
(\mathrm{cm})\end{array}$ & $\begin{array}{l}\text { Period } 1 \\
\text { April-October } 1995\end{array}$ & $\begin{array}{l}\text { Period } 2 \\
\text { Aug } 1996 \text { - May } 1997\end{array}$ \\
\hline \multirow{4}{*}{ Carangidae } & Trachurus spp. & $5-35$ & April-May & August-October and May \\
\hline & Naucrates ductor & $5-30$ & May-August & August-May \\
\hline & Seriola spp. & $3-20$ & June-October & August-February \\
\hline & Pseudocaranx dentex & $2-20$ & July-October & August-February and May \\
\hline \multirow[t]{2}{*}{ Coryphaenidae } & Coryphaena hippurus & $70-100$ & May-June & August-September and November \\
\hline & C. equiselis & 50 & June-August & \\
\hline Balistidae & Balistes carolinensis & $25-30$ & July-August & October-November \\
\hline Kyphosidae & Kyphosus sectator & $10-20$ & April-October & December-February and May \\
\hline Sphyraenidae & Sphyraena viridensis & 10 & June & \\
\hline Sparidae & Boops boops & $5-10$ & July & \\
\hline Centrolophidae & Schedophilus ovalis & $10-50$ & April & August-November and February-May \\
\hline \multirow{3}{*}{ Scombridae } & Scomber japonicus* & $18-22$ & & August \\
\hline & Katsuwonus pelamis* & $3-5 \mathrm{Kg}$ & June-August & August-September \\
\hline & Thunnus alalunga* & $4-7 \mathrm{Kg}$ & & August-September \\
\hline Carcharhinidae & Prionace glauca* & $120 \mathrm{Kg}$ & & September \\
\hline
\end{tabular}

TABLE 2. - Abundance of fish (in $\mathrm{Kg}$ ) from visual counts along the studied period (Mean biomass taken, Standard Deviation, Maximal biomass recorded in one visit and Total biomass located beneath the FAD).

\begin{tabular}{llrrr}
\hline SPECIES & Mean & SD & Max & Total \\
\hline Trachurus spp. & 0.18 & 0.57 & 3.00 & 8.15 \\
Naucrates ductor & 1.40 & 3.28 & 13.02 & 61.79 \\
Seriola spp. & 0.11 & 0.22 & 1.00 & 5.01 \\
Pseudocaranx dentex & 0.93 & 2.43 & 10.00 & 41.13 \\
Coryphaena spp. & 6.69 & 25.35 & 150.00 & 294.20 \\
Balistes carolinensis & 0.08 & 0.27 & 1.40 & 3.50 \\
Kyphosus sectator & 0.05 & 0.10 & 0.35 & 2.15 \\
Sphyraena viridensis & $4 \times 10^{-4}$ & $3 \times 10^{-3}$ & 0.02 & 0.02 \\
Boops boops & $4 \times 10^{-3}$ & 0.03 & 0.20 & 0.20 \\
Schedophilus ovalis & 0.33 & 0.92 & 3.50 & 14.40 \\
& & & & \\
\hline
\end{tabular}

Seriola spp., Trachurus picturatus (Bowdich, 1825), P. dentex, Kyphosus sectator (Linnaeus, 1758), Boops boops (Linnaeus, 1758) and Sphyraena viridensis (Jordan and Evermann, 1896), were only represented by juveniles, while Coryphaena spp. and Balistes carolinensis (Gmelin, 1788), were only represented by adults. Naucrates ductor and Schedophilus ovalis (Cuvier and Valenciennes, 1833) were represented by adult and juvenile individuals. Scomber japonicus (Houttuyn, 1788), K. pelamis, T. alalunga and Prionace glauca (Linnaeus, 1758) were registered only through fishing in the vicinity of FADs.

Seriola spp., $N$. ductor, and P. dentex were the most frequently observed species under FADs (60, 56 and $47 \%$ of observations respectively). Trachurus spp., S. ovalis, and K. sectator were noted in 24 , 25 and $30 \%$ of the observations respectively. Coryphaena spp. were found beneath the FADs in $11 \%$ of the observations, while $B$. carolinensis, $B$. boops and $S$. viridensis were rarely encountered (7, 2 and $2 \%$ respectively) around the FADs.

\section{Aggregated fish biomass}

There were significant differences in the fish biomass under FADs by month (ANOVA, $\mathrm{F}=2.17$, $\mathrm{P}=0.039$ ), with the maximum aggregations in September (Fig. 3). Although the number of species underneath FADs increased significantly with the immersion time (ANOVA, $\mathrm{F}=2.90, \mathrm{P}=0.023$; Pearson's correlation $\mathrm{r}=0.4503, \mathrm{P}<0.001, \mathrm{~N}=53$; Fig. 4), the fish biomass aggregated did not (ANOVA, $\mathrm{F}=0.94, \mathrm{P}=0.46$ ). The average biomass found was $8.93 \mathrm{Kg}(\mathrm{SD}=23.6)$; however, when only baitfish (juvenile fish) were taken into account, the mean biomass aggregated was $3.38 \mathrm{Kg}(\mathrm{SD}=4.84)$, with a maximum of $23.37 \mathrm{Kg}$. The census where Coryphaena spp. was present offered a mean aggre-

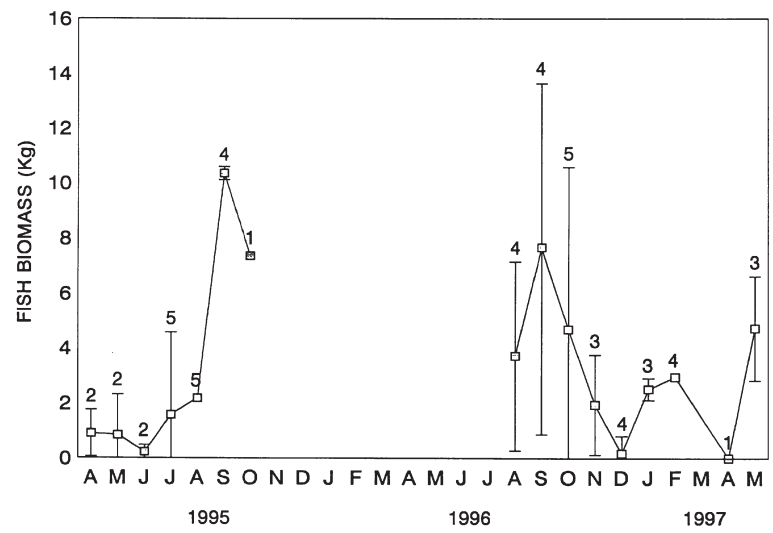

FIG. 3. - Changes in abundance in fish biomass over the study period (the figures on top of bars indicated the maximum number of species counted each month). 


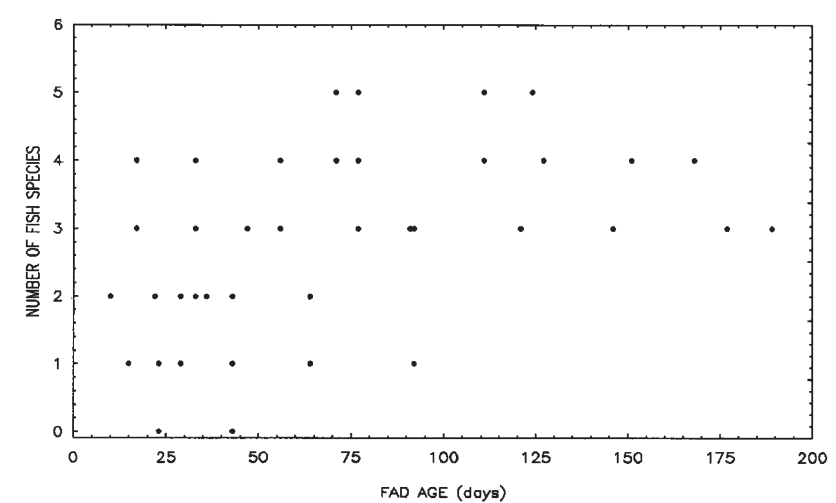

FIG. 4. - Variation in the number of fish species with the length of time that the devices were in place (Pearson's correlation $r=0.4503$, $\mathrm{P}<0.001, \mathrm{~N}=53)$.

gated biomass of $53.9 \mathrm{Kg}(\mathrm{SD}=53.6)$, with a maximum of $150 \mathrm{Kg}$.

The FADs deployed in shallower waters gave an aggregated biomass which was significantly lower for baitfish than for those deployed in deeper areas (ANOVA, $\mathrm{F}=3.457, \mathrm{P}=0.039$; Pearson's correlation $r=0.4417, \mathrm{P}<0.001, \mathrm{~N}=53$; Fig. 5). The largest number of species registered in any one census of a single FAD was five (mean=2.72; $\mathrm{SD}=1.31$ ). However, we observed a significant difference in the number of species present as a function of the anchoring depth of the FADs (ANOVA, $\mathrm{F}=4.484, \mathrm{P}=0.016$ ). Generally, the FADs deployed on shallower waters gave a lower number of species aggregated.

\section{Fish behaviour around FADs}

Depending on the size of the individuals, the schools of juvenile $P$. dentex and Trachurus spp. aggregated under the protection of fragments of net hanging from the flotsam (Fig. 1) or deeper, always close to the rope (the juveniles smaller than $5 \mathrm{cms}$. in length, of both species, frequently established

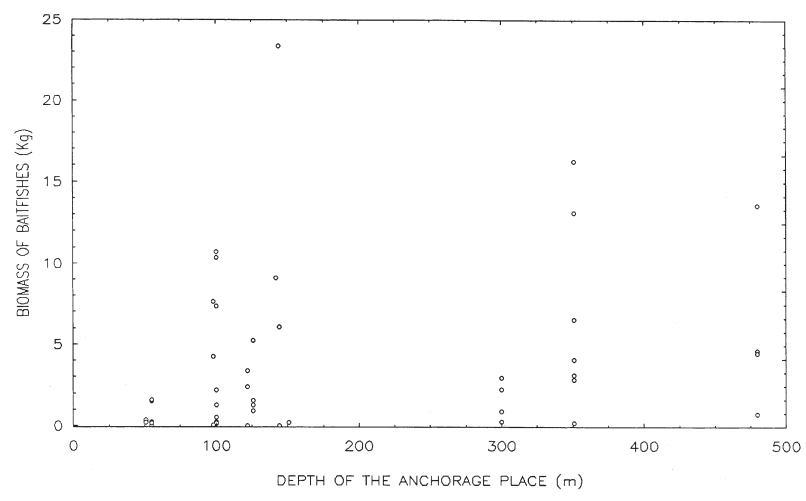

FIG. 5. - Variation of the baitfish biomass under FAD with the depth of anchorage (Pearson's correlation $\mathrm{r}=0.4417, \mathrm{P}<0.001, \mathrm{~N}=53$ ).

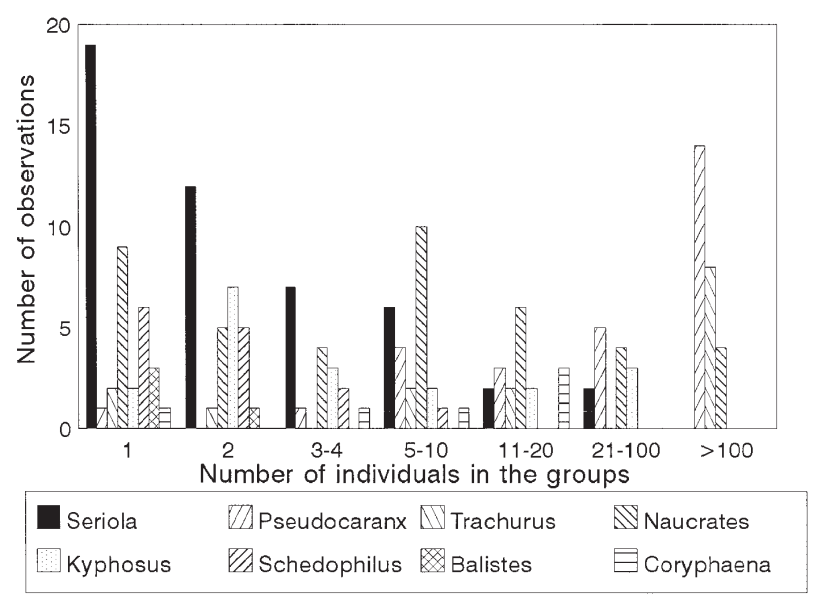

FIG. 6. - Number of observations of group size for each species counted by divers.

mixed schools). The juvenile $P$. dentex even aggregated around other fish such as $B$. carolinensis, when they were close to the FAD. These juveniles, when they reached a body length of between 15 and $20 \mathrm{cms}$, moved no further than $20 \mathrm{~m}$ from the FAD, aggregating around whatever object passed closeby, even the divers, and later returning to the proximity of the FAD when the object moved further than 20 $\mathrm{m}$ from the same. Frequently, these individuals swam to deep waters following the anchorage rope, out of the visible range of divers (over $30 \mathrm{~m}$ ).

The juvenile of Seriola spp. and Schedophilus ovalis were solitary or constituted small loose groups of 2-5 individuals (Fig. 6). Those smaller than $10 \mathrm{cms}$. did not move away from the refuge of the submerged structure of the float. Juvenile of $K$. sectator less than $15 \mathrm{~cm}$ long took refuge between the hanging nets of the FAD, while larger specimens were observed up to $20 \mathrm{~m}$ away. Aggregated juveniles $(5-10 \mathrm{~cm})$ and adults $(30-50 \mathrm{~cm})$ of $S$. ovalis remained a few centimetres under the float.

A male and two females of Coryphaena spp were observed and video recorded during courting/ spawning around a FAD. This species was normally observed, aggregated in small groups of under 15 individuals (Fig. 6).

\section{The fouling community}

The fouling community of the FADs was composed of algae and invertebrates, especially Cirripedia and Hydrozoans. The most abundant invertebrate was Lepas anatifera (Linné) which began the colonization of the FADs two week after deployment and completed it after four months (colonizing 
the flotsam, nets and the rope). Between the hanging nets of the FAD, colonized by hydrozoans and algae, the amphipod Caprella acutifrons Latreille and the crab Planes minutus (Linnaeus) were frequently detected.

The most frequent algae were Hiucksia mitchelliae (Harvey) P.C. Silva, followed by Polysiphonia myrioccoca Montagne and its epiphyte Audouinella microscopica (Nägeli) Woelkerling.

\section{Fish captures around FADs}

Two hundred tons of tuna (K. pelamis and $T$. alalunga) were caught in the vicinity of one FAD between August and September 1996. These catches had a market value of US\$ 323 thousand, thus the cost of this FAD represented only $0.13 \%$ of the obtained catch value. During the 1995 and 1996 fishing seasons (from June to October), commercial catches of Katsuwonus pelamis around FADs fluctuated between 200 and $7000 \mathrm{~kg}$ per fishing day and per FAD, whilst the average catch was approximately $1000 \mathrm{~kg}$. The catches of Coryphaena spp. fluctuated between 10 and $400 \mathrm{~kg}$ per fishing day and per FAD, giving an average catch of $100 \mathrm{~kg}$.

\section{DISCUSSION}

During our observations, fish under or near the FADs were generally juveniles belonging to eight species and five families (although we registered nine families and 15 species of fish). Seriola spp., Naucrates ductor and Pseudocaranx dentex were the most common species.

In agreement with Rountree (1990), our observations indicated that seasonally regulated juvenile fish availability, as a consequence of the natural recruitment processes in the region, is apparently the most important factor determining FAD species composition and abundance. Most of the species registered around FADs in the Canary Islands spawn during Spring or at the beginning of Summer (i.e. carangids) (Fischer et al., 1981), so recruitment to the area peaks at the end of the Summer.

However, there are other factors which also seem to have an effect. The abundance of the fauna under FADs was affected by the depth of the anchorage. But, contrary to what we initially expected, the FADs deployed in shallower waters showed a lower biomass and a reduced number of aggregated species. This result may be biased by the character- istics of the shelf of the island (very narrow and abrupt) where deeper anchorage areas are not far enough from the shore when compared with shallower ones. On the other hand, floats undergo a maturation process (Arenas et al., 1992) and it is possible that since older FADs are more completely colonized by a fouling community (algae, hydrozoans and crustaceans, hence available food resources), they can support a higher aggregated biomass, and with increasing maturity, the diversity of species in the communities increases. Nevertheless, the age of FADs (immersion time) had no effect on the aggregated biomass, unlike the number of species aggregated,which increased proportionately in the way we expected.

As pointed out by Hunter and Mitchell (1968) and Feigebaum et al. (1989) juvenile fish probably congregate around flotsam looking for the shelter that FADs provide. In general, the fish observed around our FADs were distributed spatially in accordance with their body size, with the smaller individuals to the FAD, taking refuge between the hanging net and the same. It is also possible that fish found local high concentration of available food under flotsam (Gooding and Magnuson, 1967) or around the FADs. Most of the natural drifting devices (i.e. drift algae, limbs, etc) are carried away by currents which come from places where floats are frequently generated (i.e. a river mouth or coastal areas) and introduced into the pelagic environment (Hunter and Mitchell, 1967). It is usually assumed that currents carry away the phytoplankton production from the region of its formation into oligotrophic regions (Vinogradov, 1983). Concentrations of biotic structures are often intensified by oceanographic features, such as fronts (Kingsford, 1993). So, some pelagic fish species could associate drifting floats and the area around them with currents where larvae and juveniles will find suitable food availability during their early life stages. This could explain the observed courting/spawning behaviour of Coryphaena spp. around FADs. We have also found anomalous and significant higher biomass of zooplankton under several anchored FADs as compared to the surrounding area (ANOVA $\mathrm{P}=0.03$; authors unpublished data) which could support the hyphothesis proposed by Gooding and Magnuson. This anomalous concentration of zooplankton may be due to eddies generated by the interaction of floats and ropes of anchorage with the current (in the same way as the current field around a boat in 
agreement with Lindquist and Pietrafesa (1989)). However, this is an issue which needs confirmation in further studies.

Most of the species observed by divers under the FADs in this study did not occur in sizes large enough to become attractive for fishing, except Coryphaena spp. and possibly N. ductor. However, FADs aggregate baitfish which are thought to attract other species of higher economic value into the general area (Rountree, 1990).

\section{ACKNOWLEDGEMENTS}

We thank Prof. Angel Luque, Dr. Asunción Viera, Dr. May Gómez, Mr Manuel Velázquez, Mr Aritz Arrizabalaga and Mr Javier Pérez for assistance with data collection. Thanks are also given to the crew of the fishing vessel Juan Carlos, Port of Arguineguín. The research was supported by the Fishing Council of the Canary Islands Government. A special word of thanks goes to Dr. Carlos Bas and Mrs M. Dolores Ojeda.

\section{REFERENCES.}

Arenas, P., M. Hall and M. García. - 1992. The association of tunas with floating objects and dolphins in the Eastern Pacific Ocean. VI. Association of fauna with floating objects in the EPO. In: International workshop on fishing for tunas associated with floating objects. (11-14 February 1992. La Jolla, California): 38 pp.

Beets, J. - 1989. Experimental evaluation of fish recruitment to combinations of fish aggregating devices and benthic artificial reefs. Bull. Mar. Sci., 44(2): 973-983.

Biais, G. and M. Taquet. - 1990. Dispositifs de concentration de poissons a la Reunion. Equinoxe, 34:20-26

Bortone, S.A., J. Van-Tassell, A. Brito, J.M. Falcon, J. Mena and C.M Bundrick. - 1994. Enhancement of the nearshore fish assemblage in the Canary Islands with artificial habitats. Bull. Mar. Sci., 55(2-3):602-608.

Brill, R.W., K.N. Holland and J.S. Ferguson. - 1984. Use of ultrasonic telemetry to determine the short-term movements and residence times of tunas around fish aggregating devices. In: Proceedings of the Pacific Congress on Marine Technology, Honolulu, Hawaii, April 24-27, 1984. Marine Technology Soc., Manoa, HI USA. Hawaii Sect 1984. pp. MRM1/1-7.

Brock, R.E. - 1985. Preliminary study of the feeding habits of pelagic fish around Hawaiian fish aggregation devices or can fad enhance local fisheries productivity. Bull. Mar. Sci., 37(1): 40-49.

Buckley, R.M., D.G. Itano and T.W. Buckley. - 1989. Fish aggregation device (FAD) enhacement of offshore fisheries in American Samoa. Bull. Mar. Sci., 44(2): 942-949.

Buckley, T.W. and B.S. Miller. - 1994. Feeding habits of yellowfin tuna associated with fish aggregation devices in American Samoa. Bull. Mar. Sci., 55(2-3): 445-459.

Cayré, P. - 1991. Behaviour of yellowfin tuna (Thunnus albacares) and skipjack tuna (Katsuwonus pelamis) around fish aggregating devices (FADs) in de Comoros Islands as determined by ultrasonic tagging. Aquat. Living Resour., 4: 1-12.

Cayré, P. and F. Marsac. - 1993. Modelling the yellowfin tuna (Thunnus albacares) vertical distribution using sonic tagging results and local environmental parameters. Aquat. Living Resour., 6(1): 1-14.
Cort, J.L. - 1990. Biología y pesca del atún rojo, Thunnus thynnus (L.), del mar Cantábrico. Publ. Espc. Inst. Esp. Oceanogr., 4: $1-272$.

de Silva, D.P. - 1982. Potential for increasing artisanal fisheries production from floating artificial habitats in the Caribean. Proc. Gulf Carib. Fish. Inst., 34: 156-167.

Fischer, W., G. Bianchi and W.B. Scott (eds). - 1981. FAO species identification sheets for fishery purposes. Eastern Central Atlantic; fishing areas 34, 47 (in part). Canada Funds-in-Trust. Ottawa, Department of Fisheries and Oceans Canada, by arrangement with the food and Agriculture Organization of United Nations, vols. 1-7.

Feigebaum, D., A. Fridlander and M. Bushing. - 1989. Determination of the feasibility of fish attracting devices for enhancing fisheries in Puerto Rico. Bull. Mar. Sci., 44(2): 950-959.

Fonteneau, A. - 1992. Pêche thoniere et objects flottants: Situation mondiale et perspectives. In: Rapport de Synthèse sur Groupe de Travail IATTC "objects flottants et thons" presenté à la 12ème Semaine des Pêches dos Açores, mars 1992: $31 \mathrm{pp}$.

Fonteneau, A. and J. Hallier. - 1993. La pesca del atun bajo objetos flotantes. Mundo Científico, 131(13): 76-77.

Friedlander, A., J. Beets and W. Tobias. - 1994. Effects of fish aggregating device design and location on fishing success in the U.S. Virgin Islands. Bull. Mar. Sci., 55(2-3): 592-601.

Frusher, S.D. - 1986. Utilization of small-scale fish aggregation devices by Papua New Guinea's artisanal fishermen. In: Maclean, J.L., L.B. Dizon and L.V. Hosillos (eds). Proceedings of the 1st Asian Fisheries Forum, Manila, Philippines, 26-31 May 1986, pp. 371-374.

Galea, J.A. - 1961. The "Kannizzati" fishery. Proceedings and Technical Papers of the General Fisheries Council for the Mediterranean, 6:85-91.

García-Gómez, A. - 1993. Primeras experiencias de crecimiento de juveniles de seriola mediterránea (Seriola dumerili Risso, 1810) alimentadas con una dieta semihúmeda. Bol. Inst. Esp. Oceanogr., 9(2): 347-360.

Gooding, R.M. and J.J. Magnuson. - 1967. Ecological significance of a drifting object to pelagic fishes. Pac. Sci., 21:486-497.

Gordo, L.S. - 1996. On the age and grwth of bogue, Boops boops (L), from the Portuguese coast. Fish. Manage. Ecol., 3(2): 157164

Greenblatt, P.R. - 1979. Associations of tuna with flotsam in the Eastern tropical Pacific. Fish. Bull., 77(1): 147-155.

Hall, M. - 1992. The association of tuna with floating objects and dolphins in the Eastern Pacific Ocean. VII. Some hypotheses on the mechanisms governing the associations of tunas with floating objects and dolphins. In: International workshop on fishing for tunas associated with floating objects. (11-14 February 1992. La Jolla, California): 6 pp.

Higashi, G.R. - 1994. Ten years of fish aggregating device (FAD) design development in Hawaii. Bull. Mar. Sci., 55(2-3): 651666.

Holland, K., R. Brill and R.K.C. Chang. - 1990. Horizontal and vertical movements of yellowfin and bigeye tuna associated with fish aggregating devices. Fish. Bull., 88(3): 493-507.

Hunter, J.R. - 1968. Fishes beneath flotsam. Sea Frontiers, 14: 280288.

Hunter, J.R. and C.T. Mitchell. - 1967. Field experiments on the attraction of fish to floating objects. J. Cons. Perm. Int. Explor. Mer, 31: 427-434.

Hunter, J. R. and C. T. Mitchell. - 1968. Association of fishes with flotsam in the offshore watters of Central America. Fish. Bull., 66(1): 13-29.

Ida, H., Y. Hiyama and T. Kusaka. - 1967. Study on fishes gathering around floating seaweed-II. Behaviour and feeding habits. Bull. Jap. Soc. Sci. Fish., 33(10): 472-478.

Isidro, H.A. - 1990. Age and growth of Trachurus picturatus (Bowdich, 1825) (Teleostei: Carangidae) from the Azores. Archipelago Cienc. Nat. Life Earth Sci., 8: 45-54.

Kihara, Y. - 1981. Fishery based on the payao method in the Philippines. Suisan Sekai, 30: 78-84.

Kingsford, M.J. - 1993. Biotic and abiotic structure in the pelagic environment: importance to small fishes. Bull. Mar. Sci., 53(2): 393-415.

Kitamado,T. and C. Kataoka. - 1996. A study for the realization of sustainable fisheries. A case of Payang fishery in the southern coast of west Jawa, Indonesia. Bull. Fac. Fish. Nagasaki Univ., 77: $117-126$ 
Kojima, S. - 1956. Fishing for dolphins in the Western part of the Japan Sea - II. Why do the fish take shelter under floating materials?. Bull. Jap. Soc. Sci. Fish., 21(10): 1049- 1052.

Kojima, S. - 1967. Studies on fishing conditions of the dolphin, Coryphaena hippurus, in the Western Regions of the Sea of Japan - XIII. "Tsukegi" as a source of food for dolphins. Bull. Jap. Soc. Sci. Fish., 33(4): 320-324.

Kwei, E.A. and P. Bannerman. - 1993. The effect of the introduction of new devices (FAD) and bird radars in the baitboat fishery of tuna in Ghana. Collect. Vol. Sci. Pap. ICCAT, 40(2): 473479. ICCAT SCRS/92/151.

Lindquist, D.G. and L.J. Pietrafesa. - 1989. Current vortices and fish aggregations: the current field and associated fishes around tugboat wreck in Onslow Bay, North Carolina. Bull. Mar. Sci., 44: $533-544$

Matsumoto, W.M., T.K. Kazama and D.C. Aasted. - 1981. Anchored fish aggregation devices in hawaiian waters. Mar. Fish. Rev., 43(9): 1-13.

Massutí, E. and O. Reñones. - 1994. Observaciones sobre la comunidad de peces pelágicos asociados a objetos flotantes en aguas oceánicas de Mallorca. Bol. Inst. Esp. Oceanogr., 10(1):81-93.

Mortensen, T. - 1917. Observations on protective adaptation and habits, mainly in marine animals. In: Papers from $\mathrm{Dr}$. Th. Mortensen's Pacific Expedition 1914-1916. Vidensk. Medd. Dansk Naturhist. Forem., 69: 57-96.

Myatt, D.O. and E. Myatt. - 1982. Midwater fish attractors. In: 1982 Record game fish. The international game fish association, pp. 57-71. Fort Lauderdale, Florida.

Parin, N.V. and B.I. Fedoryako. - 1992. Pelagic fish communities around floating objects in the open ocean. In: Groupe de Travail IATTC "objects flottants et thons" presenté à la $12^{\text {ème }}$ Semaine des Pêches dos Açores, mars 1992: 5 pp.

Pollard, D.A. and J. Matthews. - 1985. Experience in the construction and siting of artificial reefs and fish aggregation devices in
Australian waters, with notes on and a bibliography of Australian studies. Bull. Mar. Sci., 37(1): 299-304.

Rountree, R.A. - 1989. Association of fishes with fish aggregation devices: effects of structure size on fish abundance. Bull. Mar. Sci., 44(2): 960-972.

Rountree, R.A. - 1990. Community structure of fishes attracted to shallow waters fish aggregation devices off South Carolina, USA. Env. Biol. Fish., 29: 241-262.

Sacchi, J. - 1986. Les dispositifs de concentration de poissons et le développement des pêches côtières. Equinoxe, 9: 14-22.

Uda, M. - 1933. Types of skipjack schools and their fishing qualities: the shoals of 'katuwo' and their angling. Bull. Jap. Soc. Sci. Fish. 2:107-111. (Transl. by W.G. Van Campen, 1952, U.S Fish Wilds. Ser. Spec. Sci. Rep. Fish. 83: 68-78).

Vinogradov, M.E. - 1983. Open-ocean ecosystems. In: Kinne, O. (ed.), Marine ecology. A comprehensive, integrated treatise on life in oceans and coastal waters pp. 657-737. John Wiley and Sons. Chichester.

Wickham, D.A. and G.M. Russell. - 1974. An evaluation of midwater artificial structures for attracting coastal pelagic fishes. Fish. Bull., 72(1): 181-191.

Wickham, D., J. Watson and L. Ogren. - 1973. The efficacy of midwater artificial structures for attracting sport fish. Trans. Amer. Fish. Soc., 3: 563-673

Wilkins, R.M. and M.H. Goodwin. - 1989. Progress report on the evaluation of fish aggregating devices for the eastern Caribbean. In: Waugh, G.T. and M.H. Goodwin (eds), Proceedings of the thirty ninth annual Gulf and Caribbean Fisheries Institute, Hamilton, Bermuda, Nov. 1986. vol. 39: 405407.

Wood, J. - 1989. Cape Verde. Consultancy for construction and deployment of fish aggregating device (FAD) in the Republic of Cape Verde (8 April-7 June 1989). Rome-Italy FAO 1989. $26 \mathrm{pp}$. 